UNIVERSITY
OF DEBRECEN
FACULTY OF
HEALTH
NYÍREGYHÁZA

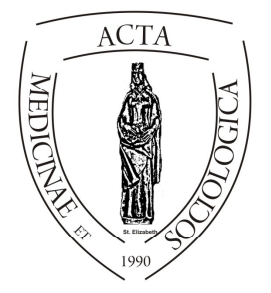

ACTA

MedSoc

VOLUME 6.

2015

\title{
A magyar nők rosszindulatú daganatos betegségek miatti korai halálozásának jellemzői 1980 és 2011 között
}

\author{
Sárváry Attila \\ Debreceni Egyetem Egészségügyi Kar Ápolástudományi Tanszék
}

\begin{abstract}
Absztrakt. A rosszindulatú daganatos betegségek a vezető halálokok közé tartoznak világszerte, Magyarországon az első helyet foglalják el a korai halálozásban mind a férfiak, mind a nők körében. A tanulmány célja a magyar nők rosszindulatú daganatos betegségek miatti korai halálozásának vizsgálata 1980 és 2011 között összehasonlítva az adatokat az Európai Uniós országok átlagával.

Az adatok a WHO Health for All Mortality adatbázisából és a Központi Statisztikai Hivataltól származnak. A deskriptív kutatásban elemeztem a 25-64, a 30-44 és a 45-59 éves női korosztály összdaganatos és a leggyakrabban előforduló rosszindulatú daganatos betegségek miatti halálozásának alakulását 1980 és 2011 között Magyarországon és az Európai Unió egyes régióiban.

A magyar nők körében a leggyakoribb rosszindulatú daganatos halálokok 2011-ben sorrendben: a tüdőrák, az emlőrák, a vastag- és végbélrák voltak. Magyarországon a daganatos halálozás a 25-64 éves nők körében már 1980-ban meghaladta az EU15 országok átlagát, és míg az EU15 országokban 2011-re a halálozás 25\%-kal csökkent, addig Magyarországon nem változott a halálozás szintje, a magyar nők halálozási kockázata 2011-ben 1,5-szerese volt az EU15 országok átlagának. A fö daganatos halálozások trendjét vizsgálva megállapítható, hogy a tüdőrák miatti halálozás a háromszorosára, az ajak, szájüreg- és garatrák miatti halálozás az ötszörösére növekedett ebben a korcsoportban a vizsgált időszakban. A 30-49 éves korcsoportban az összdaganatos halálozás-
\end{abstract}


ban 30\%-os csökkenés, míg a 45-59 éves korcsoportban közel 10\%-os növekedés volt tapasztalható.

A magyar nők korai daganatos halálozásának csökkentéséhez a rizikómagatartásformák gyakoriságának mérséklése, a már bevezetett szürőprogramok hatékonyságának növelése és a kezelés feltételeinek további javítása elengedhetetlenül fontos.

Kulcsszavak: rosszindulatú daganat, nők korai halálozása, epidemiológia

\section{The premature cancer mortality trends of Hungarian women between 1980 and 2011}

Abstract. Cancer diseases are the leading causes of mortality all over the world. In Hungary they are on the first place in premature mortality among men and women. The aim of this study is to analyze premature cancer mortality trends of Hungarian women between 1980 and 2011, and compare the data with the results of EU regions.

The sources of the data were the WHO Health for All Mortality Database and the Hungarian Central Statistical Office. In the descriptive study the all-cancer cause mortality as well as the trends of main causes of cancer mortality in the age groups of 25-64, 33-44 and 45-59 among women were analyzed in Hungary and in the different EU regions, as well.

The main causes of cancer mortality among Hungarian women in 2011 in order were: lung cancer, breast cancer and cancer of the colon, rectum and anus. In Hungary the cancer mortality was higher than in the EU15 average in 1980 and while in the EU15 countries the mortality decreased by $25 \%$ during the observed period, in Hungary the cancer mortality did not change, the relative risk of mortality of the Hungarian women were 1.5 times higher compared with the EU15 countries. Observing the trends of the main causes of cancer mortality, the mortality of lung cancer increased up to 3 times and the cancer of the lip, oral cavity and pharynx increased up to 5 times in this age group in the observed period. The all-cancer cause mortality decreased by $30 \%$ in the age group $30-44$ years and increased by approximately $10 \%$ in the age group $45-59$ years.

To decrease the cancer mortality of Hungarian women we need to control the risk factors, increase the effectiveness of the introduced screening programs and improve the treatment conditions of cancer patients.

Keywords: cancer diseases, premature mortality of women, epidemiology 


\section{Bevezetés}

A rosszindulatú daganatos betegségek a vezető halálokok közé tartoznak világszerte. E betegségek miatt a világon évente mintegy 7,6 millióan halnak meg (2008-as adat), ami az összhalálozás 13\%-a. A WHO elörejelzése szerint ez az adat folyamatosan növekedni fog. Becslésük szerint 2030-ban már mintegy 13,1 millió halálozásért lesz felelős ez a betegségcsoport. A daganatos betegségek okozta halálozás 70\%-a az alacsony és közepes jövedelmü országokban következik be (WHO 2013a). A férfiak és a nők körében különböző daganatos betegségek fordulnak elö. A világon a nők körében sorrendben a legtöbb halálozást okozó rosszindulatú daganatok: emlö-, tüdő-, gyomor-, vastag- és végbélrák, valamint a méhnyakrák (WHO 2013b). Az Európai Régió országaiban a szív- és érrendszeri betegségek után a második leggyakoribb halálok a rosszindulatú daganatok, amelyek az összhalálozás kb. 20\%-áért felelősek. Európában évente mintegy 3 millió új esetet regisztrálnak és 1,7 millió halálozás következik be, a leggyakoribb daganatos halálozásért felelős betegségek lokalizáció szerint a tüdő-, gyomor-, máj-, vastagbél- és emlőrák (WHO 2013c).

Jól ismert, hogy a magyar lakosság egészségi állapota az Európai Uniós országokéhoz képest igen kedvezőtlen képet mutat (Ádány 2012). A fő halálokok megegyeznek a fejlett országokban tapasztalható halálokokkal (szív- és érrendszeri betegségek, daganatos betegségek), azonban a fö halálokok sorrendjében és súlyában változások következtek be az utóbbi évtizedekben, különösen a korai halálozás tekintetében. Ez azt jelentette, hogy míg korábban a 25-64 éves férfiak körében a szív- és érrendszeri betegségek miatti halálozás állt az élen, 2004-töl kezdődően már a daganatos betegségek miatti halálozás vezetett (Ádány 2003; Ádány 2006). A nők körében korábban is a daganatos betegségek miatti halálozás súlya dominált a korai halálozáson belül, azonban ez a súly növekedett, míg a szív- és érrendszeri betegségek miatti halálozás súlyának csökkenése volt megfigyelhető 2004 és 2009 között (Ádány 2006, Ádány 2012). A daganatos betegségek okozta megbetegedések és halálozások korábbi elemzései azt mutatták, hogy a magyar lakosság daganatos betegségek miatti halálozása kiemelkedően magas az Európai Régióban, illetve az egyes daganatos halálokok miatti halálozás gyakorisága jelentősen változott az elmúlt évtizedekben. Ezek közül kiemelendő a tüdőrák és az ajak, szájüreg, garat rosszindulatú daganatai miatti halálozás gyakoriságának jelentős növekedése (Gaudi és Kásler 2002; Ottó és Kásler 2005; Tompa 2011). A magyar nők korai daganatos halálozásának újabb elemzését az indokolja, hogy 2013-ban véget ért a 10 éves Népegészségügyi Program, ezért érdemes áttekinteni, hogy a célkitűzések mennyire valósultak meg, illetve milyen trendek, tendenciák érvényesültek az utóbbi évtizedekben a daganatos halálozásukban. 


\section{Adat és módszer}

Az adatok egyrészt a WHO Health for All Mortality adatbázisából (WHO HFAM 2013)(2013. augusztus), másrészt a Központi Statisztikai Hivatal 2011-es Demográfiai Évkönyvéből (KSH 2012) származnak. A deskriptív kutatásban elemeztem a 25-64 éves női korosztály daganatos halálozását lokalizáció szerint 2011-ben, valamint az összdaganatos és a leggyakrabban előforduló rosszindulatú daganatos betegségek miatti halálozásának alakulását 1980 és 2011 között összehasonlítva az adatokat az Európai Unió régi tagállamainak (EU15), a 2004ben és utána csatlakozott EU országok (EU13) és a jelenleg az Európai Uniót alkotó 28 ország (EU28) átlagos halálozásával. A főbb rosszindulatú daganatos halálokokon belül további korcsoportos bontást alkalmaztam: a 30-44 és 45-59 éves korcsoportokat. Az adatbázisban szereplő halálozási adatok standardizáltak, a standard az európai standard populáció kormegoszlása. A halálozási adatok 100000 före vonatkoznak.

\section{Eredmények}

A magyar 25-64 éves nők összhalálozásában a daganatos betegségek miatti halálozás 45\%-os súllyal szerepelt 2011-ben (KSH 2012). Ebben a korcsoportban összesen 4964 rosszindulatú daganatos halálozás következett be. Lokalizáció szerint vizsgálva a daganatos halálozást a leggyakoribb halálok a tüdőrák (27\%) volt, e mellett az emlőrák $(15,8 \%)$ és a vastag- és végbélrák $(10,1 \%)$ szerepeltek jelentős súllyal. A méhnyakrák miatti halálozás az 5. helyen található, a nyirokés vérképzőrendszeri daganatokkal azonos súllyal (1. ábra).

A magyar nők (0-X éves korcsoport) rosszindulatú daganatos betegségek miatti halálozása 1980-tól a '90-es évek elejéig emelkedett, majd stagnált (2. ábra). 1999-től egy lassú csökkenés következett be a halálozásukban. A 2004-ről 2005re bekövetkezett jelentős csökkenés a halottvizsgálati bizonyítványok feldolgozásában történt változás, a kézi feldolgozásról a gépi feldolgozásra történő áttérés eredménye, nem valós csökkenés, ezért a 2005 előtti adatok nem hasonlíthatók össze a 2005 utáni adatokkal. 2005 után további stagnálás jellemezte a nők daganatos halálozását. Az EU15 országok átlagában ezzel szemben 1993-ig volt jellemző a halálozás stagnálása ettől kezdve folyamatos a halálozás csökkenése, ami a halálozási olló nyílását eredményezte a magyar halálozáshoz képest. Ennek következtében a magyar 0-X éves nők halálozási kockázata az EU15 országokban élő nőkéhez képest 2011-ben 1,4-szeres volt. 


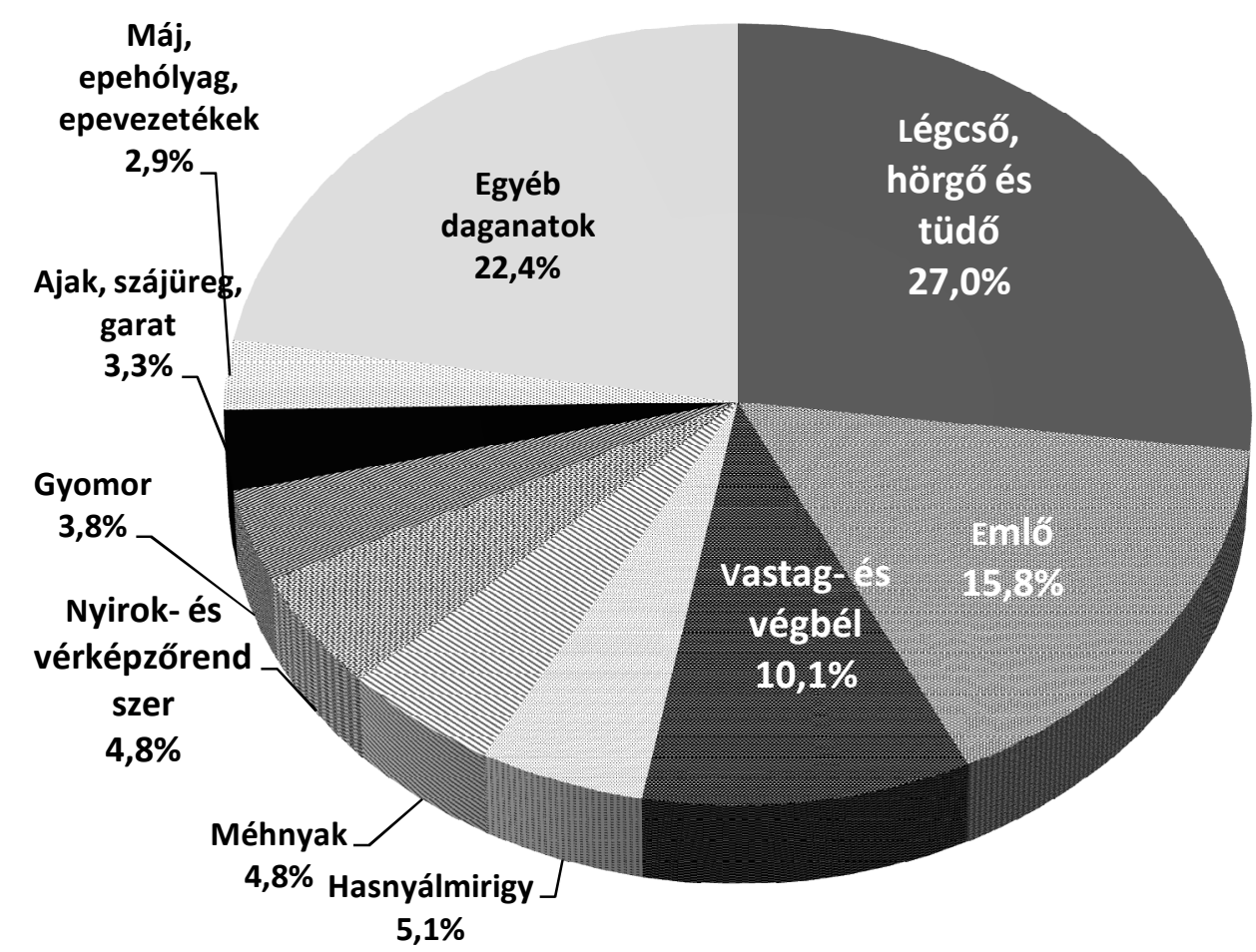

(Forrás: Demográfiai Évkönyv 2011. KSH, Bp. 2012.)

1. ábra A 25-64 éves magyar nők rosszindulatú daganatos betegségek miatti halálozásának megoszlása a daganat lokalizációja szerint, 2011.

A magyar nők korai halálozása (25-64 évesek) hasonló trendet követett, vagyis 1980-tól egy növekvő, majd stagnáló szakasz után 2003-tól egy kismértékü csökkenés következett be, 2011-ben halálozásuk megfelelt az 1980-as szintek. Az EU15 országokban ebben az időszakban kb. 30\%-os halálozáscsökkenés következett be, aminek eredményeképpen a magyar 25-64 éves nők halálozási kockázata 1,7-szerese volt az EU15 országok átlagának. A magyar nők daganatos halálozás mindkét korcsoportban meghaladta a kelet-közép-európai országok átlagát (EU13) is. 


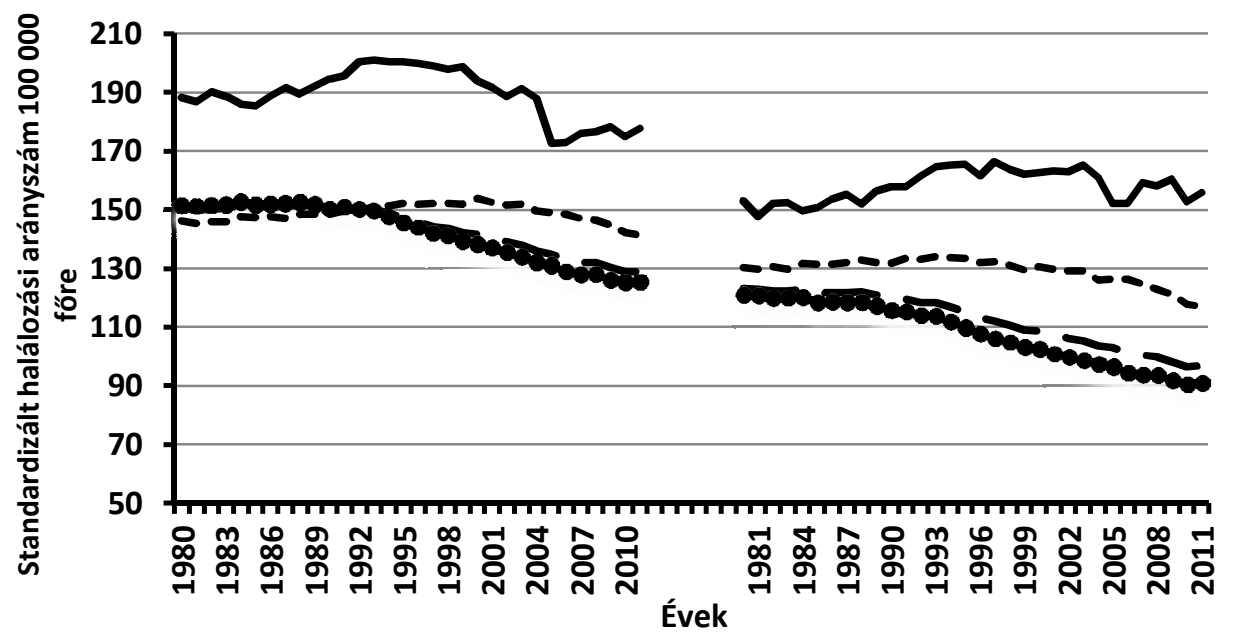

Magyarország —-EU28 —EU15 —- EU13

(Forrás: WHO HFA Mortality adatbázis, 2013. augusztus)

2. ábra A 0-X és 25-64 éves nők rosszindulatú daganatos betegségek miatti halálozásának alakulása Magyarországon és az Európai Unióban, 1980-2011. Standard: az európai populáció standard kormegoszlása.

A HFA-M adatbázisban lehetőség van 15 éves korcsoportos bontásban vizsgálni a halálozást, ezért vizsgáltam a 30-44 és a 45-59 éves korcsoport daganatos betegségek miatti halálozását. A 30-44 éves magyar nők rosszindulatú daganatos betegségek miatti halálozása 1980-tól 1997-ig emelkedett, majd csökkenni kezdett, halálozásuk 2003-ban érte el az 1980-as szintet, majd ez alá került (3. ábra). Ezzel szemben a 45-59 éves magyar nők halálozása folyamatosan emelkedett 2003-ig, ettől kezdve kismértékü csökkenés következett be. A 30-44 éves korcsoport daganatos halálozása jelentősen alacsonyabb a 45-59 korcsoporténál, ami a daganatos betegségek idősebb korban történő megjelenésével magyarázható. Nemzetközi összehasonlításban a 30-44 éves nők halálozása végig magasabb volt az EU15 országok átlagánál, 2011-ben a magyar nők halálozási kockázata 1,5-szeres volt az EU15 országok átlagos halálozásához képest. A 45-59 éves korcsoportban az EU15 országok átlagos halálozása folyamatosan csökkent a vizsgált időszakban, ennek megfelelően ebben a korcsoportban jelentősen nyílt a halálozási olló, 2011-ben a magyar 45-59 éves nők halálozási kockázata 1,8szerese volt az EU15 országok átlagához képest. 


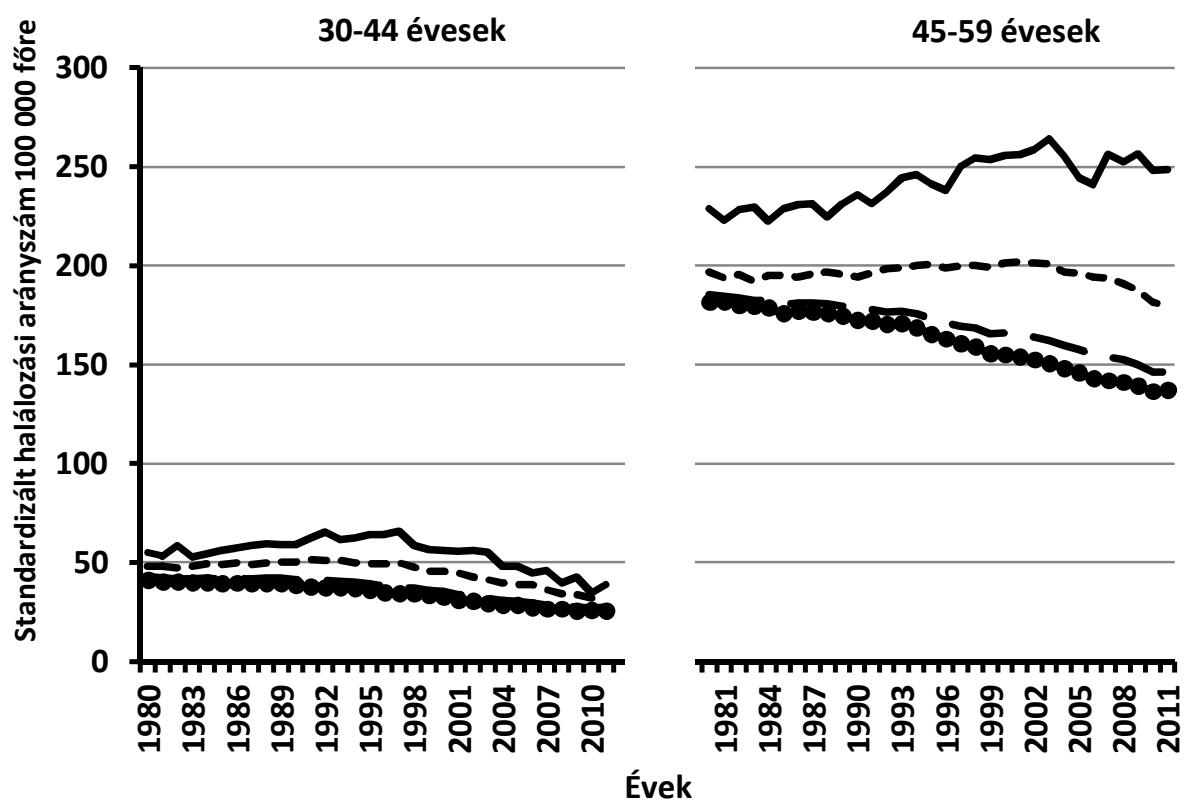

- Magyarország —-EU28 —EU15 - - EU13

(Forrás: WHO HFA Mortality adatbázis, 2013. augusztus)

3. ábra A 30-44 és 45-59 éves nők rosszindulatú daganatos betegségek miatti halálozásának alakulása Magyarországon és az Európai Unióban, 1980-2011. Standard: az euró-

pai populáció standard kormegoszlása.

A 25-64 éves korcsoportban lokalizáció szerint vizsgálva a nők daganatok miatti halálozásának alakulását megállapítható, hogy a vizsgált időszakban háromszorosára nőtt a tüdőrák (13,3/100 000-ről 42,0/100 000-re) és közel ötszörösére az ajak-, szájüreg- és garatrák (1,1/100 000-röl 5,1/100 000-re) miatti halálozásuk, míg az emlörák, a méhnyakrák és a gyomorrák miatti halálozásuk csökkent (4. ábra).A nők tüdőrákos halálozása 1980-tól egészen 2010ig folyamatosan nőtt - úgy túnik ebben az évben a halálozás elérte a csúcsát és ezzel 2001-ben megelőzte a korábban vezető emlőrák miatti halálozást. A gyomorrák és az ajak-, szájüreg- és garatrák miatti halálozás gyakorisága 2000-től kezdve azonos ebben a korcsoportban. 


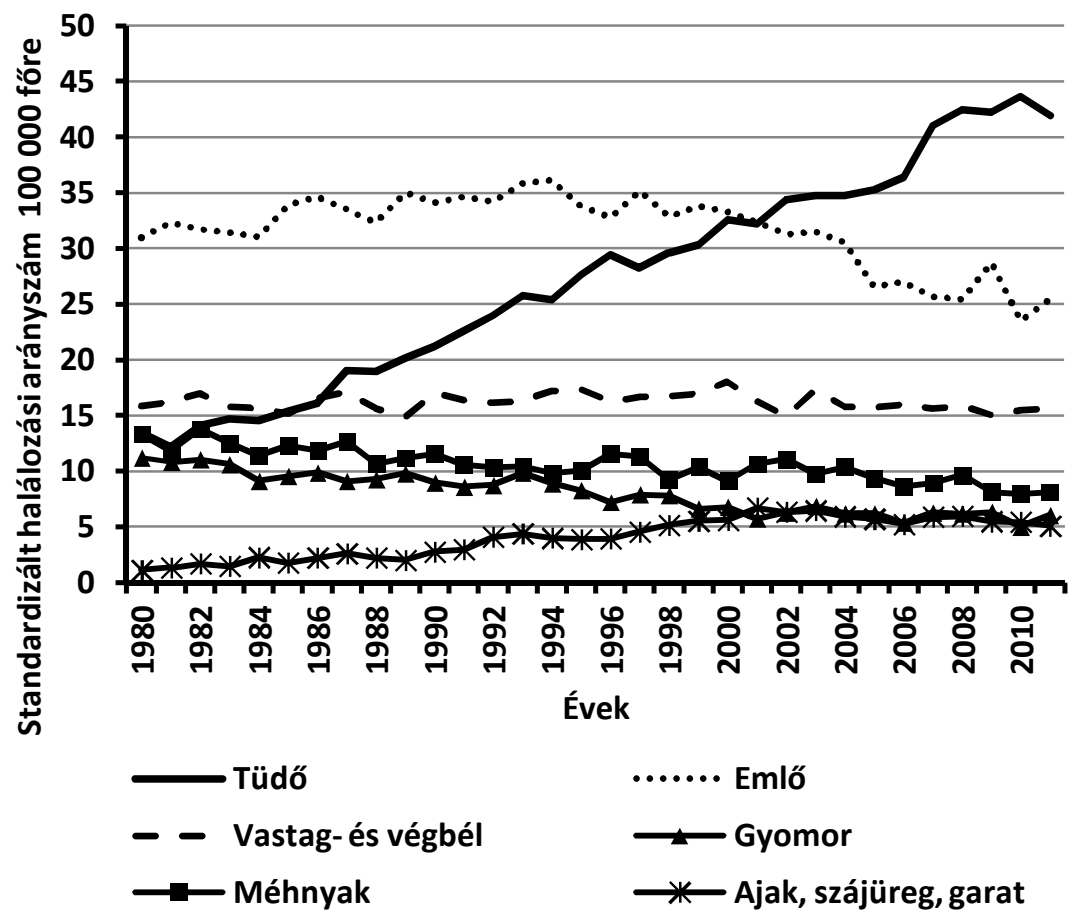

(Forrás: WHO HFA Mortality adatbázis, 2013. augusztus)

4. ábra A rosszindulatú daganatos betegségek miatti halálozás alakulása a 25-64 éves magyar nők körében a daganat lokalizációja szerint, 1980-2011. Standard: az európai populáció standard kormegoszlása.

A föbb daganatos betegségek miatti halálozást nemzetközi összehasonlításban vizsgálva a 25-64 éves magyar nők tüdőrák miatti halálozása 1980-ban még az EU országok átlagánál alig volt magasabb, a vizsgált időszakban azonban - bár az EU országokban is bekövetkezett egy növekedés - a magyar nők halálozása sokkal gyorsabban nőtt az EU országokénál. Ennek következtében a tüdőrák miatti halálozási kockázatuk 2011-ben 2,5-szerese volt az EU15 tagországok halálozási átlagának és az Európai Régió országai listáján az első helyen álltak 2011-ben. 


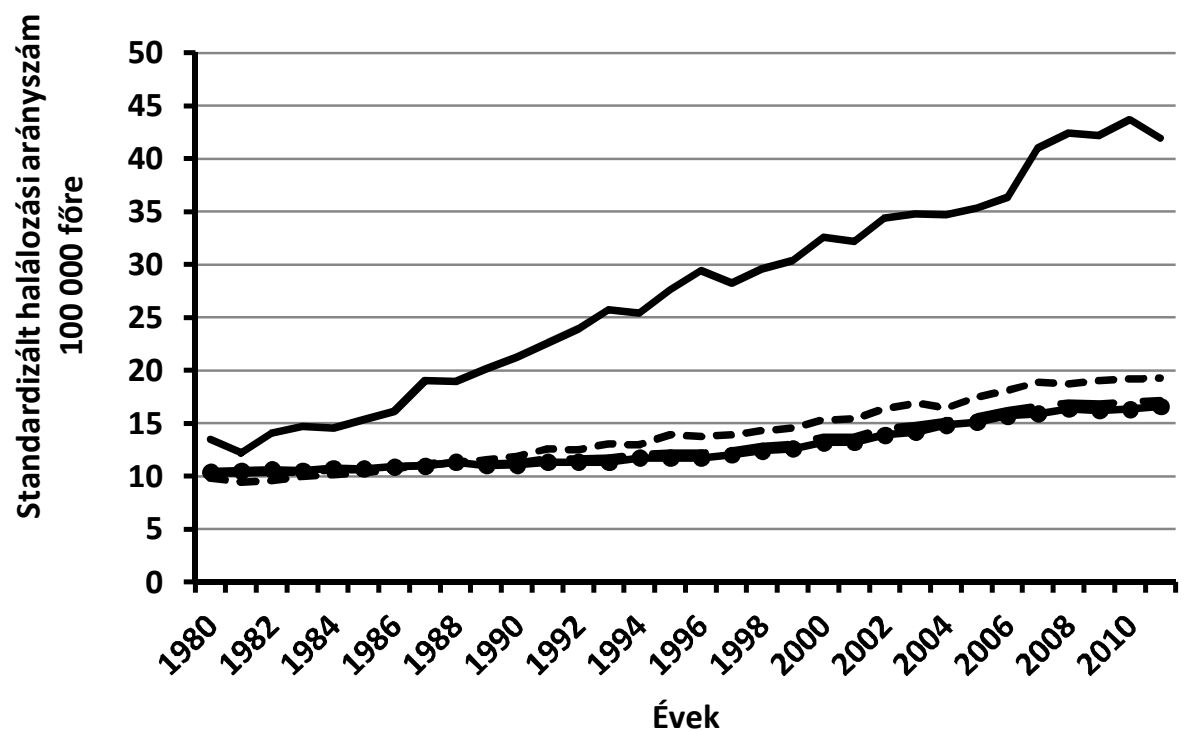

-Magyarország —EU28 —EU15 —- EU13

(Forrás: WHO HFA Mortality adatbázis, 2013. augusztus)

5. ábra A tüdőrák miatti halálozás alakulása a 25-64 éves nők körében Magyarországon és az EU egyes régióiban, 1980-2011. Standard: az európai populáció standard kormegoszlása.

A magyar nők emlőrák miatti halálozása a vizsgált időszak elején szintén megegyezett az EU15 országok halálozási átlagával. 1991-től kezdődően azonban míg a magyar nők halálozása először növekedett, majd 1994-től csökkenni kezdett, addig az EU15 országokban már 1990-től elindult a csökkenés, amely jelentősebb volt, mint a magyar nők körében, ennek következtében a magyar nők halálozási kockázata - bár nem volt túl nagy az eltérés -, de 1,2-szerese volt az EU15 országok halálozási átlagának. 


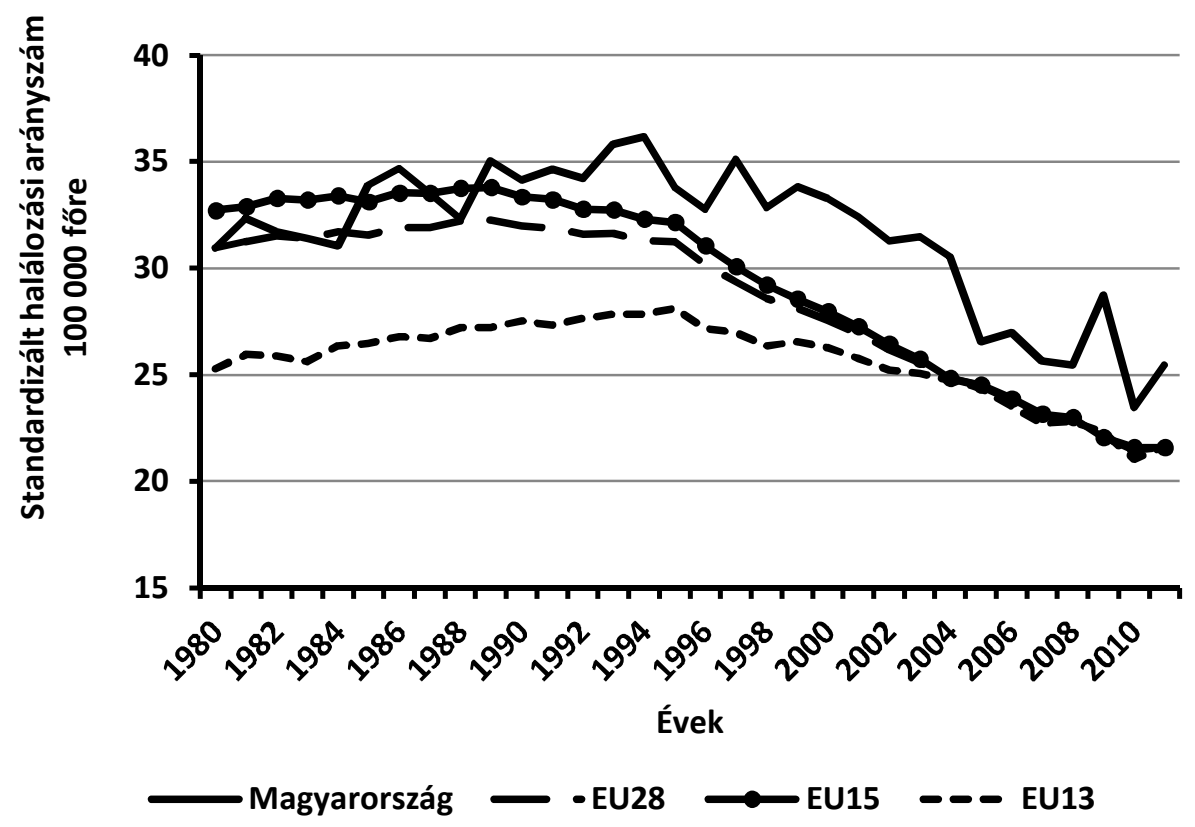

(Forrás: WHO HFA Mortality adatbázis, 2013. augusztus)

6. ábra Az emlörák miatti halálozás alakulása a 25-64 éves nők körében Magyarországon és az EU egyes régióiban, 1980-2011. Standard: az európai populáció standard kormegoszlása.

A 25-64 éves magyar nők vastag- és végbélrák miatti halálozása - kisebb eltérésekkel - gyakorlatilag nem változott 1980-tól 2011-ig és halálozásuk az időszak teljes egészében meghaladta az EU országok átlagát. Az EU15 országok halálozásában 1993-tól kezdődően folyamatosan csökkent a halálozás, e miatt 2011-ben a magyar nők halálozási kockázata 2-szerese volt az EU15 országok átlagának. 


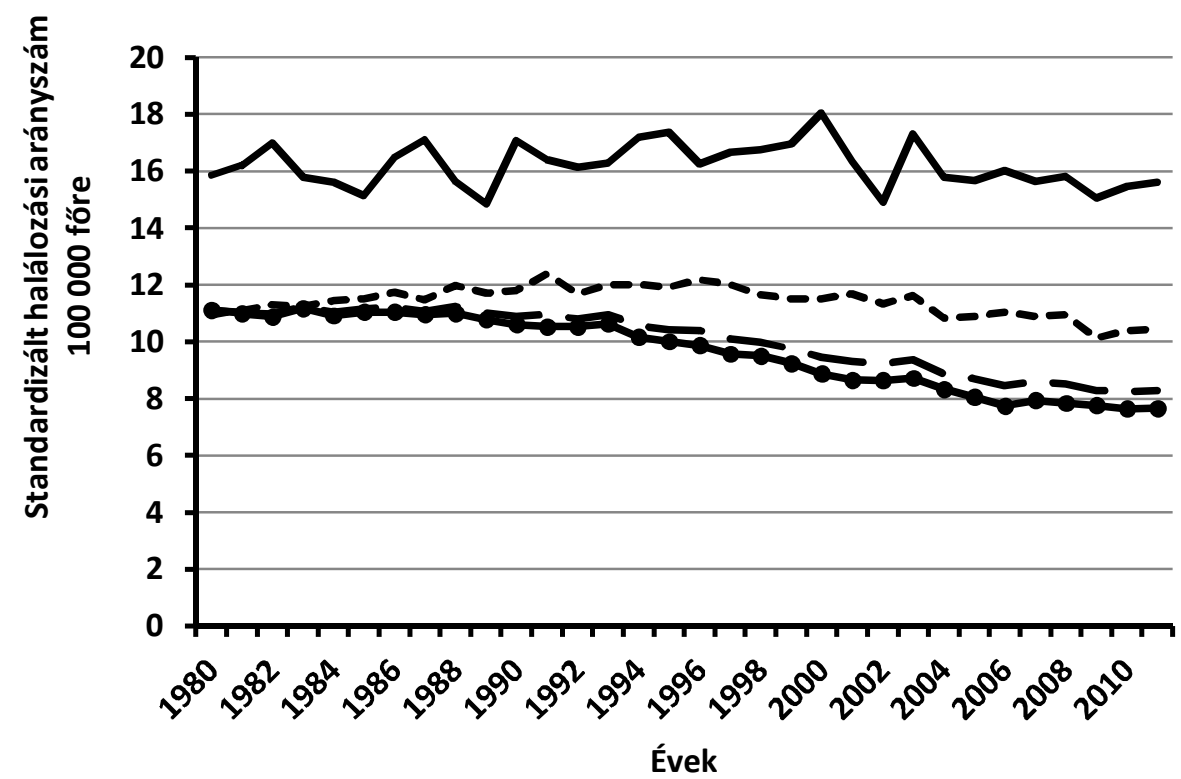

Magyarország —-EU28 —EU15 - - EU13

(Forrás: WHO HFA Mortality adatbázis, 2013. augusztus)

7. ábra A vastag- és végbélrák miatti halálozás alakulása a 25-64 éves nők körében Magyarországon és az EU egyes régióiban, 1980-2011. Standard: az európai populáció standard kormegoszlása.

A magyar nők méhnyakrák miatti halálozása 1980-ban 2,8-szorosa volt az EU15 országok átlagának és megegyezett az EU13 országok átlagával. 1980-tól csökkenő tendencia érvényesült mind a magyar nők, mind az EU15 országokban élő nők körében, ennek következtében 2011-ben a magyar nők halálozási kockázata nem csökkent, sőt nőtt 1980-hoz képest (3,1-szeres a kockázat). 


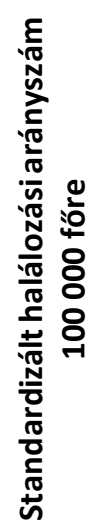

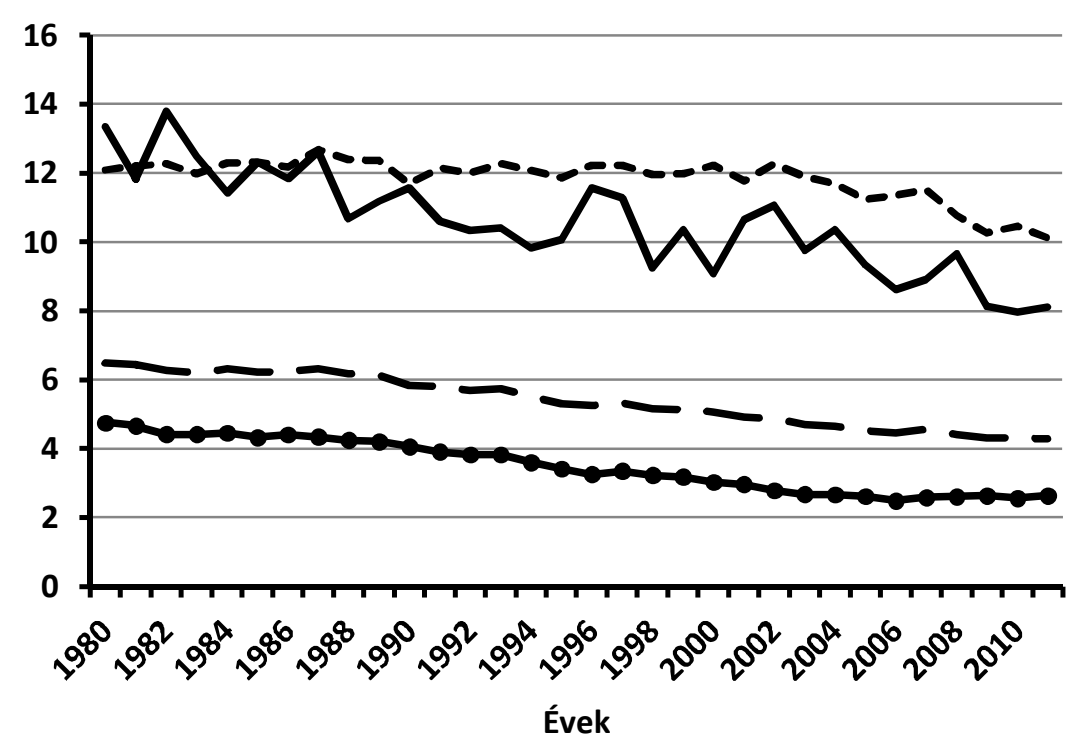

Magyarország

- EU28

$\underset{\text { EU15 }}{-15}$

EU13

(Forrás: WHO HFA Mortality adatbázis, 2013. augusztus)

8. ábra A méhnyakrák miatti halálozás alakulása a 25-64 éves nők körében Magyarországon és az EU egyes régióiban, 1980-2011. Standard: az európai populáció standard kormegoszlása.

A 30-44 éves nők körében vizsgálva a daganatok okozta halálozás lokalizáció szerinti alakulását megállapítható, hogy ebben a korcsoportban továbbra is az emlőrák áll az első helyen (9. ábra). Az emlőrák miatti halálozásuk 1980 és 1997 között kisebb-nagyobb kilengésekkel nagyjából azonos szinten volt, majd 1997-től kezdett csökkenni. A 25-64 éves korcsoporttól eltérően a tüdőrák miatti halálozásuk csak a vizsgált időszak közepéig nőtt a kiindulási érték mintegy hatszorosára (1980: 2,2/100 000-ről 1996: 12,0/100 000-re), onnantól kezdve csökkenő tendenciát mutatott. Ennek ellenére 2010-ben az Európai Régió országai között a magyar 30-44 éves nők az első helyen szerepeltek a tüdőrák mortalitás listáján. A méhnyakrák miatti halálozásuk a vizsgált időszak elején kisebb kilengésekkel stagnált, majd 2002-től csökken tendenciózusan, ezzel a tüdőrák és méhnyakrák miatti halálozás gyakorisága azonos volt az időszak végére. Az ajak-, szájüreg- és garat rosszindulatú daganatai miatti halálozás emelkedése ebben a korcsoportban is megfigyelhető volt, az időszak végére azonban a halálozás szintje visszatért az 1980-as értékre. 


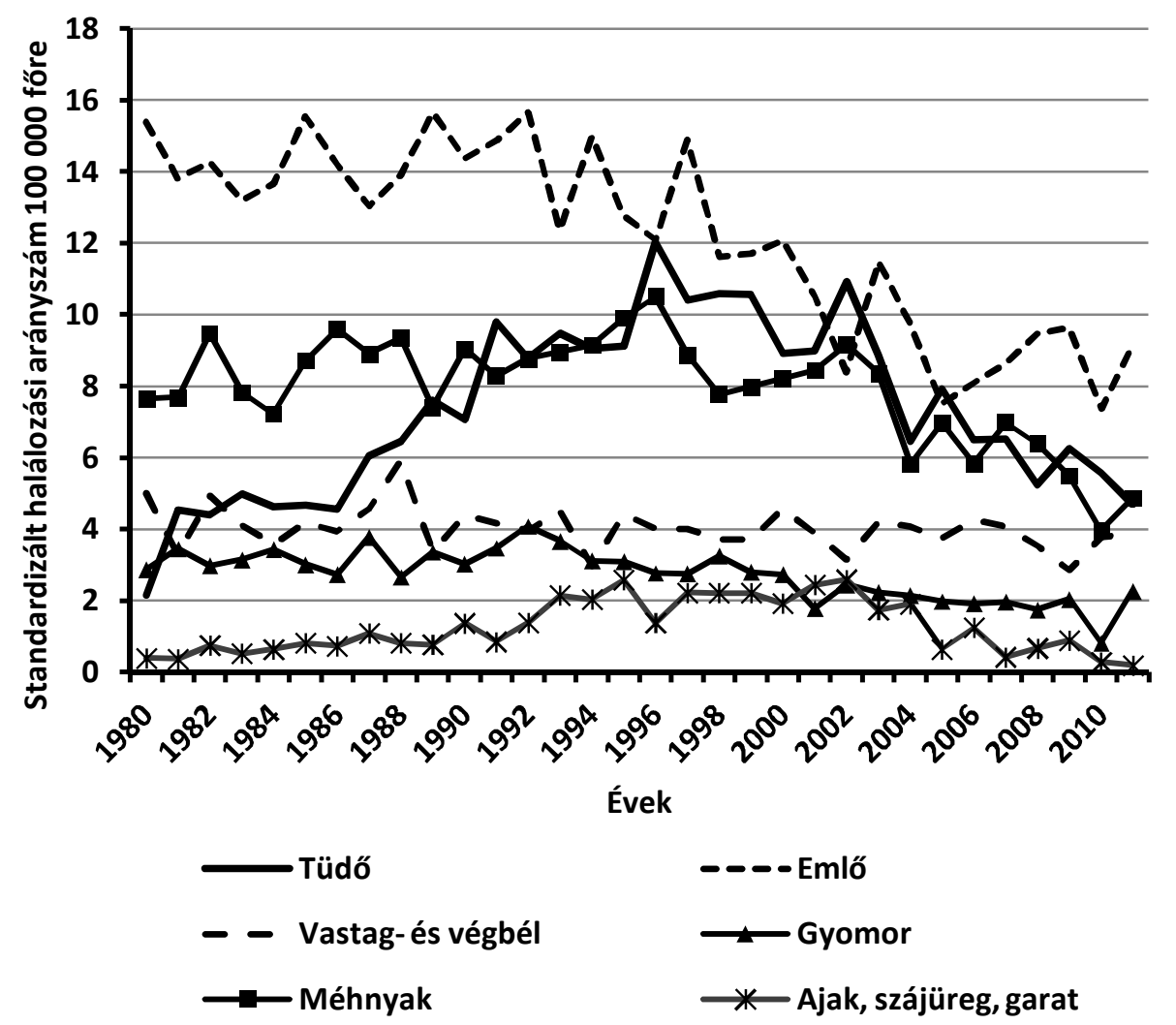

(Forrás: WHO HFA Mortality adatbázis, 2013. augusztus)

9. ábra A rosszindulatú daganatos betegségek miatti halálozás alakulása a 30-44 éves magyar nők körében a daganat lokalizációja szerint, 1980-2011. Standard: az európai populáció standard kormegoszlása.

A 45-59 éves nők lokalizáció szerinti daganatos halálozásának alakulása jellemzően azonos volt a 25-64 éves korcsoportban megfigyelhető tendenciákkal (10. ábra). A 30-44 éves korcsoporthoz képest ebben a korcsoportban az időszak egészében növekedett a tüdőrák és 2001-ig az ajak-, szájüreg-, és garatrák miatti halálozás. Az emlőrák miatti halálozásuk 1980-tól 1986-ig emelkedett, majd 1999-ig stagnált, innentől kezdve jellemző a csökkenő tendencia. A méhnyakrák miatti halálozásban elsősorban a vizsgált időszak elején következett be csökkenés, 1995-től viszont stagnálás tapasztalható. Ezzel a magyar 45-59 éves nők az Európai Régió országai között mind a tüdőrák, mind az ajak-, szájüreg-, és garatrák miatti halálozásban az első helyen álltak 2010-ben és 2011-ben. 


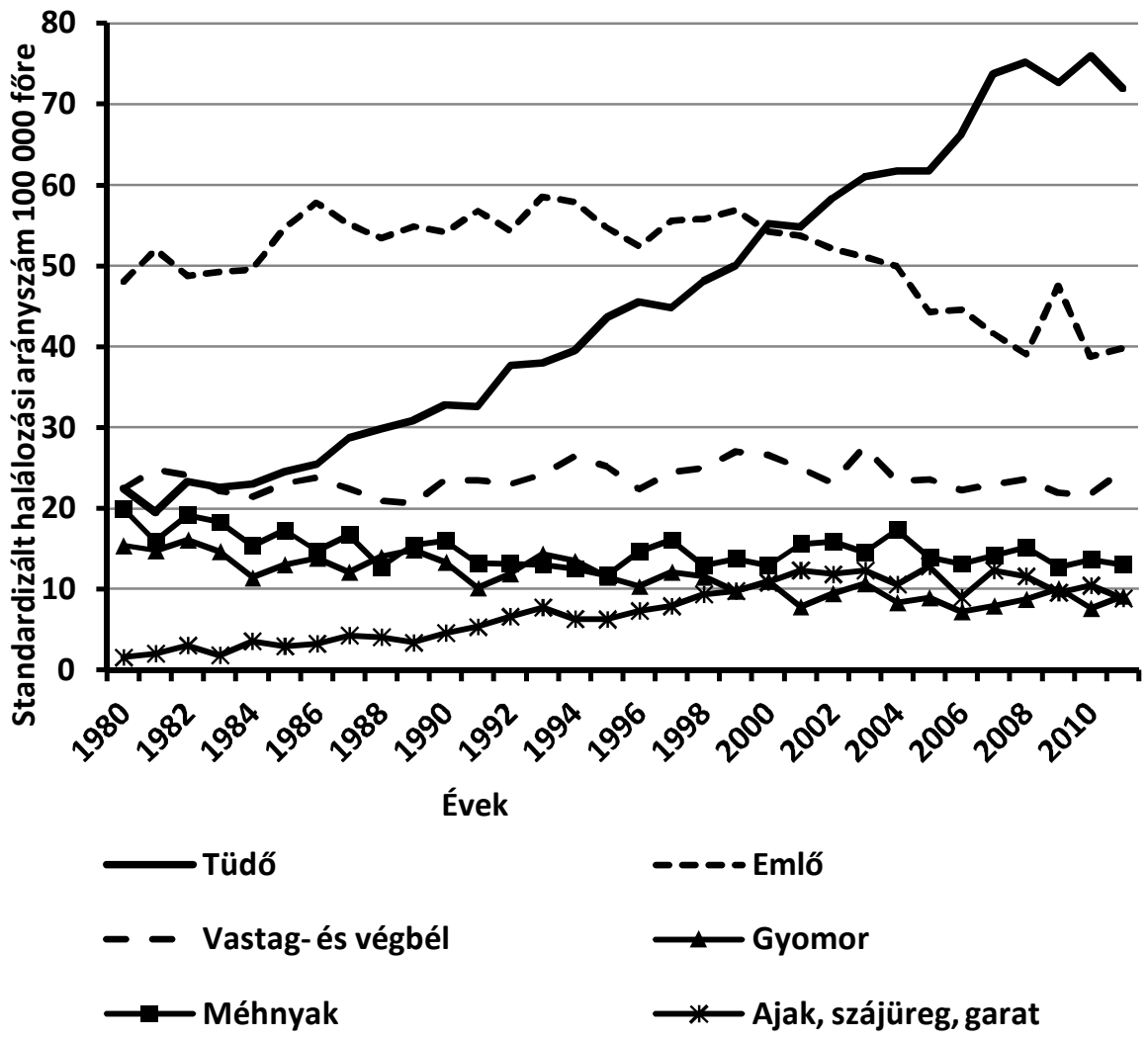

(Forrás: WHO HFA Mortality adatbázis, 2013. augusztus)

10. ábra A rosszindulatú daganatos betegségek miatti halálozás alakulása a 45-59 éves magyar nők körében a daganat lokalizációja szerint, 1980-2011. Standard: az európai populáció standard kormegoszlása.

Vizsgáltam a nők összdaganatos, tüdőrák, emlörák, vastag- és végbélrák és méhnyakrák miatti halálozásának változását korcsoportonként (25-64; 30-44; 4564) 1980 és 2011 között Magyarországon és az EU15 országokban A nők összdaganatos halálozása Magyarországon 1980-hoz képest 2011-re csak a 30-44 éves korosztályban csökkent 30\%-kal, míg a 45-59 éves korosztály esetén közel $10 \%$-os $(8,7 \%)$ növekedés volt tapasztalható. Ennek megfelelően a 25-64 éves női korosztály daganatos halálozása gyakorlatilag nem változott a vizsgált időszakban. Ezzel szemben az EU15 országokban minden vizsgált korosztályban több, mint 20\%-kal csökkent a nők halálozása, a legnagyobb mértékü csökkenés a legfiata- 
labb, 30-44 éves korosztályban következett be. A föbb daganatos halálokok közül Magyarországon a tüdőrák miatti halálozás emelkedett a legnagyobb mértékben minden vizsgált korcsoportban, a 45-59 és a 25-64 éves korcsoportban az emelkedés mértéke meghaladta a 200\%-ot, így a nők halálozása az 1980-as érték háromszorosa volt 2011-ben. Az emelkedő tendencia megfigyelhető az EU15 országaiban is, de az emelkedés mértéke jóval kisebb mértékű volt. Az emlőrák miatti halálozás mind Magyarországon, mind az EU15 országaiban minden vizsgált korcsoportban csökkent, viszont a csökkenés mértéke csak a 30-44 évesek körében haladta meg a 30\%-ot, míg az EU15 országokban ez az arány 30-40\%-os. A vastag- és végbélrák miatti halálozás csak a 30-44 éves nők körében csökkent Magyarországon, míg az EU15 országokban minden vizsgált korcsoportban több, mint 30\%-os volt a halálozáscsökkenés. A szürhető daganatok közé tartozik a méhnyakrák, amely mind Magyarországon, mind az EU15 országokban több, mint 30\%-kal csökkent a vizsgált időszakban, azonban a csökkenés mértéke az EU15 országokban négy-hat százalékponttal meghaladta a magyar adatokat.

\begin{tabular}{|c|c|c|c|c|c|}
\hline & $\begin{array}{l}\text { Összdagana- } \\
\text { tos halálozás }\end{array}$ & Tüdőrák & Emlőrák & $\begin{array}{l}\text { Vastag- és } \\
\text { végbélrák }\end{array}$ & Méhnyakrák \\
\hline Korcsoportok & \multicolumn{5}{|c|}{ Magyarország } \\
\hline 30-44 évesek & $-29,8$ & 117,1 & $-40,4$ & $-22,4$ & $-36,3$ \\
\hline 45-59 évesek & 8,7 & 220,1 & $-17,2$ & 9,9 & $-34,9$ \\
\hline 25-64 évesek & 1,7 & 212,0 & $-17,7$ & $-1,5$ & $-39,9$ \\
\hline Korcsoportok & \multicolumn{5}{|c|}{ EU15 } \\
\hline 30-44 évesek & $-37,6$ & 8,3 & $-40,4$ & $-35,7$ & $-39,6$ \\
\hline 45-59 évesek & $-24,4$ & 72,5 & $-36,0$ & $-30,2$ & $-41,2$ \\
\hline 25-64 évesek & $-24,9$ & 59,4 & $-34,0$ & $-31,1$ & $-44,4$ \\
\hline
\end{tabular}

(Forrás: WHO HFA Mortality adatbázis, 2013. augusztus)

1. táblázat Az összdaganatos és a föbb rosszindulatú daganatos betegségek miatti halálozás növekedése/csökkenése (\%) a nők körében korcsoportok szerint Magyarországon és az EU15 országaiban 1980 és 2011 között $(1980=100 \%)$.

Vastagon kiemelve a 20\%-nál nagyobb növekedés, vastagon kiemelve és dőlt betűs a 20\%-nál nagyobb mértékü csökkenés. 


\section{Összegzés}

A magyar nők korai (25-64 éves) daganatos halálozása sokkal kedvezőtlenebb az EU országok átlagánál. A főbb vezető rosszindulatú daganatos betegségek okozta halálozás ebben a korcsoportban 2011-ben sorrendben a tüdőrák, az emlőrák, valamint a vastag- és végbélrák voltak. Magyarországon a daganatos halálozás a 25-64 éves nők körében már 1980-ban meghaladta az EU15 országok átlagát és míg az EU15 országok átlagában a halálozás 25\%-kal csökkent, addig Magyarországon nem változott a halálozás szintje, e miatt nyílt a halálozási olló. A magyar nők rosszindulatú daganatos betegségek miatti halálozási kockázata 2011-ben 1,5-szerese volt az EU15 országok átlagának. A fö daganatos halálozások trendjét vizsgálva megállapítható, hogy a tüdőrák miatti halálozás a háromszorosára, az ajak, szájüreg- és garatrák miatti halálozás az ötszörösére növekedett a vizsgált időszakban. Ez a két daganatos halálok volt a felelős azért, hogy Magyarországon a nők korai (25-64 éves) halálozása nem csökkent a vizsgált időszakban annak ellenére, hogy az emlőrák és a méhnyakrák esetén jelentős halálozáscsökkenéssel számolhattunk. A magyar nők és az EU15 országokban élő nők körében a halálozási olló nyílásához az is hozzájárult, hogy míg Magyarországon a vastag- és végbélrák miatti halálozás a 30-44 éves korosztály kivételével a vizsgált időszakban stagnált, addig az EU15 országokban több, mint 30\%-os csökkenés következett be.

A rosszindulatú daganatos betegségek okozta betegségteher csökkentése megnyilvánult a 2002-ben kidolgozott és 2003-ban elfogadott Magyar Népegészségügyi Programban (Az Egészség Évtizedének Nemzeti Programja 2003). „A daganatos betegségek visszaszorítása” programpontban célként „A daganatos halálozások növekvő trendjének megállítása" szerepelt. Az ebben a programpontban felsorolt feladatok elsősorban a daganatos betegek ellátásának javítását célozták (pl. onkológiai centrumok létrehozása, az ellátáshoz szükséges infrastruktúra biztosítása, rehabilitációs intézményrendszer országos kiépítése). A rosszindulatú daganatos betegségek okozta halálozás csökkentésében bizonyos daganatos betegségek szürésének bizonyítottan szerepük van, ami a nemzetközi ajánlásokat figyelembe véve megjelent a programban. A népegészségügyi szürővizsgálatok programpontban már konkrétabb célmegjelölés szerepelt a daganatos betegségek által okozott halálozásra vonatkozóan: „A szervezett és célzott lakossági szürővizsgálatok segítségével 70 éves kor alatt 5-10\%-kal mérséklődjön a daganatos betegségek okozta halálozás 2012-ig”. A lakossági szervezett emlöszürést a 45-65 éves korcsoportban 2002 elején, a méhnyakrákszürést a 2564 éves korcsoportban 2003-ban vezették be Magyarországon. A vastag- és végbélrákszürés csak lokális, pilot programokban indult el, országos kiterjesztésére módszertani problémák miatt nem került sor. 
A Népegészségügyi program alapján 2006-ban elkészült a Nemzeti Rákellenes Program, amely összefoglalta a primer, a szekunder és a tercier prevenció szintjén a célokat és a cselekvési programokat. Ahogy az az eredményekből látható, Magyarországon a 25-64 éves nők körében 2003-ban érte el a daganatos halálozás a csúcsát, innentől kezdve kismértékü csökkenés következett be, bár az adatok értékelésénél figyelembe kell venni azt, hogy a 2004-2005 között bekövetkezett csökkenés az adatfeldolgozásban történt változás következménye. Ez alapján azt mondhatjuk, hogy a Népegészségügyi Programban kitüzött, daganatos betegségekre vonatkozó cél - a daganatos betegségek miatti halálozás növekvő trendjének megállítása - a nők esetében teljesült. Mindenképpen pozitív változások következtek be a 30-44 éves korosztály daganatos halálozásában, hiszen ebben a korcsoportban a tüdőrák kivételével a főbb rosszindulatú daganatos halálokokban jelentős csökkenése következett be, az emlörák és méhnyakrákos halálozásuk az EU15 országok halálozáscsökkenését elérte vagy megközelítette a vizsgált időszakban. Ezzel szemben a 45-54 éves korosztály esetén - ahol mindkét szervezett lakossági szürővizsgálat bevezették - árnyalja a képet, hogy bár az emlörák és a méhnyakrák miatti halálozásuk is csökkent, az emlörákos halálozáscsökkenés kb. 50\%-kal, a méhnyakrák miatti halálozás csökkenés 6\%kal maradt el az EU15 országok átlagától. A szürővizsgálat által érintett két daganatos betegség esetén az is kérdéses, hogy a halálozás csökkenésében a szürésnek milyen szerepe volt, ugyanis az emlörákos halálozás jelentős csökkenése következett be a 30-44 éves korosztályban 1997-töl kezdve (ahol nincs szervezett szürés) és a 45-54 éves korosztályban is 1999-től kezdve, tehát már a szürés bevezetését megelőzően. Ehhez még érdemes hozzátenni, hogy a szürésen való részvételi arányok is elmaradtak a kívánatos 70\%-os szinttől, 40\%-50\% körül mozgott (Boncz, Sebestyén és mtsai 2005; Boncz, Sebestyén és mtsai 2008; Kovács és Boncz 2009; Boncz, Döbrőssy és mtsai 2013a; Boncz, Döbrőssy és mtsai 2013b). A méhnyakrák szervezett szürésének bevezetése sem érte el a kívánt célt 2011-ig (60\%-kal csökkenjen a méhnyakrák okozta halálozás a 25-64 éves korcsoportban 2012-ig - Magyar Népegészségügyi Program), bár a csökkenés mértéke jelentős volt mindhárom korcsoportban, a 45-64 évesek esetén a csökkenés a vizsgált időszak legelején, 1980 és 1995 között következett be, onnantól kezdve stagnált, ami a szürővizsgálatok és/vagy a daganatos betegek ellátásának hiányosságait jelentik.

A két legnagyobb mértékben emelkedett - tüdőrák, ajak-, szájüreg- és garatrák - daganatféleség rizikófaktorai - kiemelten a dohányzás, valamint a túlzott alkoholfogyasztás - jól ismertek. A magyar nők körében elsősorban a dohányzás gyakorisága emelkedett a 2000-es években, a rendszeres dohányzók aránya a felnőtt nők körében 2000-ben 23\% (OLEF 2002), 2003-ban 25\% (OLEF 2005) volt. Azóta számos törvény született Magyarországon a dohányzás visszaszorítására. A másodlagos megelőzés tekintetében a szájüregi daganatok szürésére 
három egészségügyi szakdolgozói csoportot jelöltek meg: a fogorvosokat, a háziorvosi és a foglalkozás-egészségügyi orvosokat. A szürés modell program keretében el is indult (Döbrőssy, Bánóczy és mtsai 2007). A tüdőrák szürésére bizonyítottan hatékony eszköz az alacsony dózisú CT alkalmazása, amelynek eredményességéről jelenleg még csak pilot vizsgálati adatok állnak rendelkezésre Magyarországon (Aberle, Adams és mtsai 2011; Moizs, Strausz és mtsai 2013) A magyar nők korai daganatos halálozásának csökkentéséhez a rizikómagatartásformák gyakoriságának mérséklése, elsősorban a dohányzás visszaszorítása és a már bevezetett szüröprogramok hatékonyságának növelése, illetve a kezelés feltételeinek további javítása elengedhetetlenül fontos.

\section{Felhasznált irodalom}

1. Ádány Róza (szerk) (2003): A magyar lakosság egészségi állapota az ezredfordulón. Medicina Kiadó, Budapest.

2. Ádány Róza (szerk) (2006): Megelőző orvostan és népegészségtan. Medicina Kiadó, Budapest.

3. Ádány Róza (szerk) (2012): Megelőző orvostan és népegészségtan. Medicina Kiadó, Budapest.

4. Aberle DR, Adams AM, Berg CD, et al. (2011): Reduced lung-cancer mortality with lowdose computed tomographic screening. N Engl J Med; 365:395-409.

5. Az Egészség Évtizedének Nemzeti Programja (2003). 46/2003. (IV. 16.) OGY határozat. (http://www.oefi.hu/nepeuprg.pdf) (Letöltve: 2014. 01. 08)

6. Boncz Imre, Sebestyén Andor, Döbrőssy Lajos Péntek Zoltán, Kovács Attila, Dózsa Csaba, Budai András, Ember István (2005): A magyar szervezett lakossági emlőszürés részvételi arányainak meghatározása az első szürési ciklusban (2002-2003). Orvosi Hetilap, 146: 1963-1970.

7. Boncz Imre, Sebestyén Andor, Döbrőssy Lajos, Péntek Zoltán, Kovács Attila, Budai András, Kövi Rita, Ember István (2008): A szervezett emlőszürési program második ciklusának (2004-2005) részvételi arányai. Orvosi Hetilap, 149:1491-1498.

8. Boncz Imre, Döbrőssy Lajos, Péntek Zoltán, Kovács Attila, Budai András, Vajda Réka, Sebestyén Andor (2013a): A szervezett emlőszürési program harmadik (2006-2007) szürési ciklusának részvételi arányai. Magyar Onkológia, 57: 140-146.

9. Boncz Imre, Döbrőssy Lajos, Péntek Zoltán, Kovács Attila, Budai András, Imre László, Vajda Réka, Sebestyén Andor (2013b): A szervezett országos 
emlőszürési program negyedik (2008-2009) szürési körének részvételi arányai. Orvosi Hetilap, 154: 1975-1983.

10. Döbrőssy Lajos, Bánóczy Jolán, Kovács Attila, Budai András, Cornides Ágnes (2007): Szájüregi szürővizsgálatok: tervek az alkalomszerű szürés kiterjesztésére Magyarországon. 148: 1267-1271.

11. Döbrőssy Lajos, Kovács Attila, Budai András, Simon Judit, Horváth Andrea Rita, Cornides Ágnes, Tulassay Zsolt (2011): A vastag- es végbéldaganatok szürésének vitatott kérdései: klinikai és népegészségügyi nézőpontok ütközése. Orvosi Hetilap, 152: 1223-1232.

12. Gaudi István, Kásler Miklós (2002): A rosszindulatú daganatos halálozás változása 1975 és 2001 között Magyarországon. Magyar Onkológia, 46: 291-296.

13. Kovács Attila, Boncz Imre (2009): A szekunder prevenciós onkológiai szürési programok helyzete Magyarországon. Népegészségügy, 87: 265-274.

14. Központi Statisztikai Hivatal (2012): Demográfiai Évkönyv 2011. KSH, Budapest.

15. Moizs Mariann, Strausz János, Rakvács Marianna, Lelovics Zsuzsanna, Bajzik Gábor, Repa Imre (2013): Az alacsony dózisú CT-vel történő tüdőrákszürés kezdeti lépései és első eredményei (absztrakt). Népegészségügy, 91: 195-196.

16. Nemzeti Rákellenes Program (2006). Egészségügyi Szakképző és Továbbképző intézet, Budapest.

17. Ottó Szabolcs és Kásler Miklós (2005): A hazai és nemzetközi daganatos halálozási és megbetegedési mutatók alakulása. Magyar Onkológia, 49:99-107.

18. Országos Lakossági Egészségfelmérés 2000. Országos Epidemiológiai Központ, Budapest, 2002.

(http://www.oefi.hu/olef/OLEF2000/Jelentesek/OLEF_osszefoglalo_jelente s.pdf) (Letöltve: 2014. 01. 08)

19. Országos lakossági Egészségfelmérés 2003. Országos Epidemiológiai Központ, Budapest, 2005.

(http://www.oefi.hu/olef/OLEF2003/Jelentesek/EgeszsegmagatartasOLEF2 003.pdf) (Letöltve: 2014. 01. 08)

20. Tompa Anna (2011): A daganatos betegségek előfordulása, a hazai és a nemzetközi helyzet ismertetése. Magyar Tudomány, 172, 11:1333-1345.

21. World Health Organization Regional Office for Europe. Health for All Mortality Database, 2013. augusztus. (http://www.euro.who.int/en/dataand-evidence/databases/mortality-indicator-database-mortality-indicatorsby-67-causes-of-death,-age-and-sex-hfa-mdb) (Letöltve: 2013. 10. 06.)

22. World Health Organization (2013a): Factsheet No297.(www.http://www.who.int/mediacentre/factsheets/fs297/en/index.ht ml) (Letöltve: 2014. 01. 06.) 
23. World Health Organization (2013b):10 factsaboutcancer.

(http://www.who.int/features/factfiles/cancer/en/index.html)(Letöltve: 2014. 01. 06.)

24. World Health Organization (2013c): Cancer; Data and statistics. (http://www.euro.who.int/en/health-topics/noncommunicablediseases/cancer/data-and-statistics)(Letöltve: 2014. 01. 06.)

\section{Sárváry Attila}

A szerző a Debreceni Egyetem Egészségügyi Kar föiskolai tanára, az Ápolástudományi Tanszék vezetője. Szakterülete a népegészségügy, ezen belül elsősorban a kisebbségek és migránsok egészségi állapotával és a gyermekek egészségmagatartásával foglalkozik. 